ISSN 0103-5150

Fisioter. Mov., Curitiba, v. 26, n. 1, p. 71-78, jan./mar. 2013

Licenciado sob uma Licença Creative Commons

\title{
The influence of body composition assessed by dual- -energy $x$-ray absorptiometry on functional capacity of patients with chronic obstructive pulmonary disease
}

\author{
Influência da composição corporal avaliada pela \\ absorciometria duoenergética na capacidade funcional em \\ pacientes com doença pulmonar obstrutiva crônica
}

\author{
Gualberto Ruas $^{[a]}$, Gabriel Gomes Ribeiro ${ }^{[b]}$, Juliane Moreira Naves ${ }^{[b]}$, Mauricio Jamami ${ }^{[c]}$ \\ [a] Physiotherapist, doctoral student, Post-Graduation Physiotherapy Program, Federal University of São Carlos (UFSCar), \\ collaborating professor of the Physiotherapy course, Federal University of Triângulo Mineiro (UFTM), Uberaba, MG - \\ Brazil, e-mail: gualbertoruas@yahoo.com.br \\ [b] Physiotherapy students at Federal University of Triângulo Mineiro (UFTM), Uberaba, MG - Brazil, e-mails: \\ ggrfsa@hotmail.com, juliane675@hotmail.com \\ [c] Physiotherapist, assistant professor, Post-Graduation Physiotherapy Program (Department of Physiotherapy), Federal \\ University of São Carlos (UFSCar), SP - Brazil, e-mail: jamami@power.ufscar.br
}

\begin{abstract}
Introduction: The individual with chronic obstructive pulmonary disease (COPD) can experience a significant reduction of body composition, peripheral muscle dysfunction, resulting in a negative influence on functional capacity. Objectives: To analyze the influence of body composition assessed by dual-energy $\mathrm{x}$ -ray absorptiometry on functional capacity of patients with chronic obstructive pulmonary disease (COPD). Materials and methods: Eleven male patients with COPD (COPDG), seven presenting moderate obstruction and four severe, and 11 sedentary male subjects (CG) were evaluated by dual-energy x-ray absorptiometry to assess their body composition. All subjects also performed the 6-minute walk test (6MWT) and Step Test (6MST) to assess their functional capacity. Results: No significant differences were found between groups for anthropometric data such as age, weight, height and body mass index (BMI). However, the COPDG presented Forced Vital Capacity (FVC), Forced Expiratory Volume in one second $\left(\mathrm{FEV}_{1}\right), \mathrm{FEV}_{1} / \mathrm{FVC}$ ratio, Maximal Voluntary Ventilation (MVV), Walked Distance (WD) and Number of Steps (NS) significantly lower than the CG ( $p<0.05$, Student's $t$-test). The Body Bone Mass (BBM), BBM\%, Lean Mass (LM), LM\%, and Right Lower Limb (RLL) and Left Lower Limb (LLL) were significantly lower in the COPDG when compared
\end{abstract}


with the CG, presenting statistically significant positive correlations with 6MWT's WD and 6MST's NS ( $p<0.05$, Pearson's test). Conclusion: We conclude that body composition is an important prognostic factor for patients with COPD, which reinforces the importance of assessing body composition by dual-energy absorptiometry since it has demonstrated with satisfactory accuracy in clinical practice. Moreover, it is a useful parameter for evaluation and reassessment in pulmonary rehabilitation programs.

Keywords: Body composition. Dual-energy absorptiometry. Functional capacity.

\section{Resumo}

Introdução: O indivíduo com doença pulmonar obstrutiva crônica (DPOC) pode apresentar uma redução importante da composição corporal, resultando em disfunção muscular periférica influenciando negativamente a capacidade funcional. Objetivos: Analisar a influência da composição corporal avaliada pela absorciometria duoenergética na capacidade funcional em portadores de DPOC. Materiais e métodos: Foram avaliados 11 indivíduos do sexo masculino portadores de DPOC, sendo sete com obstrução moderada e quatro, grave (GDPOC) e 11 indivíduos sedentários do sexo masculino (GC), por meio da absorciometria duoenergética para avaliar a composição corporal, e do teste de caminhada de seis minutos (TC6) e teste do degrau (TD6) para avaliar a capacidade funcional. Resultados: Não houve diferenças significativas intergrupos nos dados antropométricos como idade, peso, altura e índice de massa corporal (IMC). No entanto, o GDPOC apresentou Capacidade Vital Forçada (CVF), Volume Expiratório Forçado no primeiro segundo $\left(V E F_{1}\right)$, relação $V E F_{1} / C V F$, Ventilação Voluntária Máxima (VVM), Distância Percorrida (DP) e Número de Degraus (ND) significativamente menores que o GC ( $p \leq 0,05$, teste $t$ de Student). Entretanto, a Massa Óssea Corporal (MOC), \% MOC, Massa Magra (MM), $\%$ MM e MM do Membro Inferior Direito (MID) e Membro Inferior Esquerdo (MIE) no GDPOC foram significativamente menores que no GC, obtendo correlações positivas estatisticamente significantes com a DP no TC6 e $N D$ no TD6 ( $p \leq 0,05$, teste de Pearson). Conclusão: Concluímos que a composição corporal é um importante fator de prognóstico para pacientes com DPOC, o que reforça a importância da avaliação da composição corporal pela absorciometria duoenergética, uma vez que tem demonstrado com precisão satisfatória na prática clínica. Além disso, é um parâmetro útil de avaliação e reavaliação em programas de reabilitação pulmonar.

Palavras-chave: Composição corporal. Absorciometria duoenergética. Capacidade funcional.

\section{Introduction}

The chronic obstructive pulmonary disease (COPD) is a respiratory disorder characterized by an existing airflow chronic obstruction that is not fully reversible (1). The airflow obstruction is usually progressive and associated with a lung inflammatory response to toxic or noxious particle and/or gases, primarily cigarette smoking (1). It is actually a disease associated with clinically significant systemic changes (1).

In addition, just as it happens in other inflammatory diseases, the COPD patient may present an important body composition reduction (bone mineral density, muscle mass and tissue depletion) (2). Unfortunately, it is a negative prognostic factor, independent from the obstruction degree, being associated with morbidity and mortality increase (3); probably due to the systemic inflammation characterized by high levels of tumor necrosis factor- $\alpha$ and interleukin 6, hypoxia and dyspnea (4).

Another condition that may contribute to body composition reduction is the malnutrition itself, since it leads to protein metabolism to generate substrate (5), resulting in peripheral muscle dysfunction, which negatively influence on the ability to perform exercises, activities of daily life and quality of life, regardless of the respiratory functional deficit (5). This muscle dysfunction involves functional, structural and bioenergetics changes, resulting in functional capacity decrease (6).

Different submaximal tests have been described for functional capacity evaluation of patients with respiratory diseases (7). This study focus on two: the 6-minute walk test (6MWT) and the 6-minute step test (6MST), once no studies, applying these tests, were found comparing them with a COPD patients' 
whole body composition assessment by dual-energy x-ray absorptiometry (DEXA).

According to Lukaski (8), DEXA is considered the "golden standard" technique to assess body compartments, considering that it directly measures muscle mass, adipose tissue and bone density accurately and precisely.

Therefore, it becomes necessary to assess the influence of body composition on the functional capacity during physical exercise, considering that weight and high isolated do not differentiate fat from muscle mass or lean mass, thus demonstrating the importance of assessing the body composition by DEXA (9).

The aim of this study was to analyze the influence of body composition assessed by dual-energy x-ray absorptiometry on functional capacity of patients with COPD.

\section{Materials and methods}

This study was undertaken in patients with COPD diagnosis who were led to the facility's Respiratory Functional Reeducation Program. All participants (COPD Group and Control Group) have signed a free informed consent, as determined by the Brazilian National Health Council Resolution n. 196/96. Assessments occurred at the Federal University of São Carlos, São Carlos (SP), Brazil.

The patients included were male, with COPD clinical diagnosis, presenting $\mathrm{FEV}_{1} / \mathrm{FVC}<70 \%$ and $30 \% \leq \mathrm{FEV}_{1}<80 \%$ predicted measured by spirometry, ex-smokers, without clinical history of respiratory symptoms or infection exacerbations, clinically stable, with no orthopedic, cardiovascular, neurological impairments and/or cognitive problems that could compromise the evaluation.

\section{COPD Group (COPDG)}

Thirty-one subjects with COPD diagnosis presenting moderate to severe obstruction (10) were initially evaluated. Four subjects with moderate obstruction were excluded because they were absent from more than three scheduled evaluation dates, and three for presenting bone deformities and rheumatic diseases that could interfere with the functional tests. Five subjects with severe obstruction dropped out claiming personal problems and domiciliary oxygen long-term continuous therapy. Five subjects did not undertake the tests because they were hemodynamically unstable, and three refused to take part in the study. Eleven subjects have completed the evaluations (seven moderate and four severe).

\section{Control Group (CG)}

Fifteen male, sedentary, nonsmoker, clinically stable, with no orthopedic, cardiovascular, neurological impairments and/or cognitive problems that could compromise the evaluation were evaluated. Four subjects were excluded because they did not complete the evaluation. Eleven subjects completed the evaluations. Both groups underwent an anamnesis and a physical exam when data, such as weight, height and age, were collected.

\section{Procedures}

The complete evaluation took place on different non-consecutive days, and comprehended:

\section{Spirometry}

All patients and healthy subjects performed a spirometry test following the Brazilian Society of Pulmonology and Pulmonary Diseases Guidelines (11), thereby measuring the slow vital capacity (SVC), forced vital capacity (FVC), forced expiratory volume in one second $\left(\mathrm{FEV}_{1}\right), \mathrm{FEV}_{1} / \mathrm{FVC}$ ratio, peak expiratory flow (PEF), forced expiratory flow between $25-75 \%$, (FEF25-75\%), and maximal voluntary ventilation (MVV) values.

\section{Body composition assessment}

The body composition was assessed by DEXA (Dual-Energy X-ray Absorptiometry), on a DPX-L (Lunar ${ }^{\circledR}$ Excellent in Imaging version 4.7e, Madison, Wisconsin, EUA) equipment, duly calibrated and under daily quality control according to the manufacture's specifications. All measurements were performed by a capacitated medical radiologic technician. A whole body scan was made, each measurement lasted about 20 minutes. The subjects were 
wearing only shorts and t-shirts, were barefoot and bearing no portable metallic object or any other accessory close to the body. All subjects remained lying and still in the supine position, feet together and arms slightly away from the side of the body on the equipment's table until the measurement were finished. After the whole body scan, the program provided estimates of body bone mass (BBM), fat mass (FM), and lean mass (LM). In this system, the limbs were delimited and separated from the trunk and the head by standard lines generated by the equipment itself. The lines were adjusted, by the same technician, following specific anatomical references determined by the manufacturer (8).

\section{Functional evaluation tests}

The functional evaluation tests conducted were the 6-minute walk test (6MWT) and the 6-minute step test (6MST).

The 6MWT general principle was based on the recommendations established by the American Thoracic Society (12). During the tests, the subjects were encouraged with pre-standardized phrases, every 30 seconds, and were also informed about the tests' remaining time.

\section{Six-minute walk test (6MWT)}

It was performed in a flat corridor with 30 meters length and 1.5 meter wide. The measured parameters recorded to monitor the subject were pulse oxygen saturation $\left(\mathrm{SpO}_{2}\right)$ and heart rate (HR), by Nonin ${ }^{\circledR}$ model 8500A (Minnesota, USA) portable pulse oximeter, and dyspnea sensation and lower limbs (LL) fatigue/pain, by the modified Borg CR10 scale. The walked distance (WD) was recorded at the end of the test. Blood pressure was also measured, before and after the test, by using a mercury sphygmomanometer (Oxigel ${ }^{\circledR}$, São Paulo, SP, Brazil) with the patient seated.

\section{Six-minute step test (6MST)}

The 6MST was performed on a $20 \mathrm{~cm}$-high step, with anti-sliding rubber surface (13), with no support for upper limbs. The subjects were instructed to step up and down the step as fast as possible for six minutes, alternating the LL so that the pain would not cause the test interruption. The number of steps up and down (NS) was recorded. During the test, $\mathrm{SpO}_{2}$ and HR were continually monitored by using a portable pulse oximeter $\left(\mathrm{Nonin}^{\circledR}{ }^{\circledR}\right.$, modelo $8500 \mathrm{~A}$, Minnesota, USA).

\section{Statistical analysis}

The InStat statistical program, version 3.05 (GraphPad Software, Inc., San Diego, CA, USA) was used to analyze the results of the present study. The analyzed variables are expressed as mean values \pm standard deviation (SD). Considering the normal distribution of the variables, determined by the Komolgorov and Smirnov test, the unrelated Student's $t$-test was used for comparisons between groups, and the related Student's $t$-test for comparisons intragroup. For correlation analysis between variables, Pearson correlation coefficient was used. The significance level was set at $\mathrm{p} \leq 0.05$.

\section{Results}

The CG and COPDG subject's anthropometric characteristics and spirometric measurements are presented on Table 1. The analysis between groups showed no significant differences for anthropometric characteristics such as age, weight, height and BMI between groups. However, the COPDG presented FVC, $\mathrm{FEV}_{1}, \mathrm{FEV}_{1} / \mathrm{FVC}$ and MVV significantly lower than the CG (Student's $t$-test; $\mathrm{p} \leq 0.05$ ).

\section{Body Composition}

The COPDG'S BBM, BBM\%, LM, LM\%, and RLL's LM and LLL's LM were significantly lower than the CG's (Table 1).

\section{Functional Capacity (6MWT and 6MST)}

The COPDG presented WD and NS significantly lower than the CG as shown on Table 1. 
Table 1 - CG and COPDG anthropometric characteristics, spirometric measurements, body composition, functional capacity assessed by 6MWT and 6MST

\begin{tabular}{ccc}
\hline & CG & COPDG \\
\hline Age (years) & 11 men & 11 men \\
Weight (kg) & $72 \pm 6$ & $69 \pm 8$ \\
Height (cm) & $174 \pm 5$ & $66 \pm 7$ \\
BMI (kg/m²) & $24 \pm 2$ & $21 \pm 2$ \\
FVC (\%pred) & $100 \pm 10$ & $80 \pm 16^{*}$ \\
VEF $1 \%$ pred) & $85 \pm 14$ & $60 \pm 14^{\star}$ \\
FEV $/$ FVC (\%) & $92 \pm 6$ & $57 \pm 6^{*}$ \\
MVV (\%pred) & $86 \pm 14$ & $57 \pm 14^{*}$ \\
BBM (kg) & $2,2 \pm 0,3$ & $1,3 \pm 0,5^{*}$ \\
BBM\% & $8 \pm 0,3$ & $3,5 \pm 0,5^{*}$ \\
LM (kg) & $61 \pm 4$ & $45 \pm 4^{*}$ \\
LM\% & $79,2 \pm 4$ & $71 \pm 16^{*}$ \\
FM (kg) & $18 \pm 4$ & $16 \pm 4$ \\
FM\% & $25,5 \pm 6$ & $24 \pm 5$ \\
RLL's LM (kg) & $8,8 \pm 1$ & $6,4 \pm 1^{*}$ \\
LLL's LM (kg) & $8,5 \pm 2$ & $6,1 \pm 1^{*}$ \\
WD (m) & $591 \pm 91$ & $434 \pm 23^{*}$ \\
NS & $100 \pm 2$ & $77 \pm 4^{*}$ \\
\hline
\end{tabular}

Source: Research data.

Notes: Data are expressed as mean \pm standard deviation; $\mathrm{CG}=$ control group; $\mathrm{COPDG}=\mathrm{COPD}$ group; $6 \mathrm{MWT}=$ six-minute walking test; $6 \mathrm{MST}=$ six-minute step test; $\mathrm{kg}=$ kilograms; $\mathrm{cm}=$ centimeter; $\mathrm{kg} / \mathrm{m}^{2}=$ kilogram per square meter; $F V C=$ forced vital capacity; FEV $_{1}=$ forced expiratory volume in one second; $F E V_{1} / F V C=$ forced expiratory volume in one second and forced vital capacity ratio; MVV = maximal voluntary ventilation; \%pred $=$ percentage from predicted; $\mathrm{BBM}=$ body bone mass; $\mathrm{LM}=$ lean mass; FM\% = fat mass percentage; $\mathrm{RLL}=$ right lower limb; $\mathrm{LLL}=$ left lower limb; $\mathrm{kg}=$ kilogram; $\%=$ percentage; $\mathrm{WD}=$ walked distance; NS $=$ number of steps climbed; $\mathrm{m}=$ meter; ${ }^{*}=$ significant; $p \leq 0.05$

\section{Correlation between 6MWT's WD and body composition in CG and COPDG}

Statistically significant positive correlations were observed between 6MWT's WD and BBM, BBM\%, LM, LM\% and RLL's LM and LLL's LM (Table 2).

\section{Correlation between 6MST's NS and body composition in CG and COPDG}

Statistically significant positive correlations were observed between 6MST's NS and BBM, BBM\%, LM, LM\% and RLL's LM and LLL's LM (Table 3).

Table 2 - Correlation between 6MWT's WD and body composition in CG and COPDG

\begin{tabular}{ccc}
\hline & CG (r) & COPDG (r) \\
\hline WD vs. BBM (kg) & $-0,293$ & $0,682^{*}$ \\
WD vs. BBM\% & $-0,117$ & $0,632^{*}$ \\
WD vs. LM (kg) & $-0,033$ & $0,642^{*}$ \\
WD vs. LM\% & $-0,133$ & $0,639^{*}$ \\
WD vs. FM (kg) & $-0,034$ & 0,012 \\
WD vs. FM\% & 0,182 & 0,015 \\
WD vs. RLL's LM & $-0,012$ & $0,721^{*}$ \\
WD vs. LLL's LM & $-0,014$ & $0,711^{*}$ \\
\hline
\end{tabular}

Source: Research data.

Notes: $\mathrm{CG}=$ control group; $\mathrm{COPDG}=\mathrm{COPD}$ group; $\mathrm{WD}=$ walked distance; $\mathrm{BBM}=$ body bone mass; $\mathrm{LM}=$ lean mass; $\mathrm{FM}=$ fat mass; RLL = right lower limb; $L L L=$ left lower limb; vs. $=$ versus $; \mathrm{kg}=$ kilogram; $\%=$ percentage $; r=$ correlation coefficient; ${ }^{*}=$ significant $(p \leq 0.05)$.

Table 3 - Correlation between 6MST's NS and body composition in CG and COPDG

(Continues)

\begin{tabular}{ccc}
\hline & CG (r) & COPDG (r) \\
\hline NS vs. BBM (kg) & 0,176 & $0,691^{*}$ \\
NS vs. BBM\% & 0,045 & $0,712^{*}$ \\
NS vs. LM (kg) & 0,163 & $0,651^{*}$ \\
NS vs. LM\% & 0,130 & $0,662^{*}$ \\
NS vs FM (kg) & 0,010 & 0,015
\end{tabular}


Table 3 - Correlation between 6MST's NS and body composition in CG and COPDG

(Conclusion)

\begin{tabular}{clc}
\hline & CG $(r)$ & COPDG $(r)$ \\
\hline NS vs FM\% & 0,1639 & 0,019 \\
NS vs RLL's LM & 0,150 & $0,642^{*}$ \\
NS vs LLL's LM & 0,052 & $0,614^{\star}$ \\
\hline
\end{tabular}

Source: Research data.

Notes: $\mathrm{CG}=$ control group; $\mathrm{COPDG}=\mathrm{COPD}$ group; NS = number of steps climbed; BBM = body bone mass; LM: lean mass; $\mathrm{FM}=$ fat mass; $\mathrm{RLL}=$ right lower limb; $\mathrm{LLL}=$ left lower limb; vs: versus; $\mathrm{kg}=$ kilogram; $\%=$ percentage; $r=$ correlation coefficient; ${ }^{*}=$ significant $(p \leq 0.05)$.

\section{Discussion}

The present study made it possible to identify that BBM, BBM\%, LM, LM\%, RLL's and LLL's LM, WD, NS, $\mathrm{FVC}, \mathrm{FEV}_{1}, \mathrm{FEV}_{1} / \mathrm{FVC}$ and $\mathrm{MVV}$ are lower in patients with COPD when compared with subjects exhibiting similar anthropometric characteristics.

Body composition is a determinant factor associated with exercise intolerance (14), and its reduction affects the peripheral muscles functions because of two different phenomena: progressive muscle mass loss and dysfunction of the remaining muscles. Some studies $(14,15)$ have demonstrated that this muscle dysfunction results from multiple factors, such as sedentarism, cachexia, skeletal muscle apoptosis, altered regulation of nitric oxide, individual susceptibility, electrolytes and hormones alterations, or may be, as well as, the consequence of the cigarette smoking itself and corticosteroids extended use.

Moreover, the muscle supplies are mobilized to meet the protein synthesis demand contributing to muscle depletion, limiting the subject's functional and respiratory capacity, increasing the risk for mortality $(16,17)$, which represents a serious problem.

On the present study, significant positive correlation was found comparing WD and NS with BBM, BBM\%, LM and LM\%, suggesting that the lower $\mathrm{BBM}, \mathrm{BBM} \%$, $\mathrm{LM}$ and $\mathrm{LM} \%$, the lower is the functional capacity.

According to Casaburi et al. (18), the body composition reduction may contribute to the peripheral gait muscle biomechanics and structure losses, resulting in decrease of the quadriceps' muscle strength and endurance when compared with healthy control subjects.

The significant positive correlation between RLL's LM and LLL's LM with WD and NS is another finding arising from the present study. In the attempt to explain this fact we cite, according to Dourado et al. (2), the decrease in activities that make use of the gait, while trying to avoid the dyspnea sensation, and the predominance of upper limbs daily activities.

Killian et al. (19) have suggested that peripheral muscle dysfunction compromises the exercising capacity, and have also observed in their studies that the fatigue sensation on LL is a limitation on functional capacity in COPD patients.

The fact that 6MST demands more from the LL muscles than the 6MWT caused this study to find higher Borg scale values for LL in both groups, being higher in the COPDG. Limitation on physical performance observed on 6MST may have occurred as a consequence of respiratory factors and muscle mass decrease (6).

The exercise limitation due to respiratory factors is presented by other authors $(20,21)$, and in the present study can be also justified as a consequence of the lower COPDG's VVM values when compared with the CG's values, once the ventilatory demand increases as the exercise intensity gets higher, reducing the ventilatory efficiency in the first group, and therefore reducing the exercise tolerance (22).

The body composition reduction reduces the diaphragmatic mass and contributes to respiratory muscle decrease in strength and endurance (23). As a consequence, patients who lose weight exhibit more dyspnea, higher rate of retained air and higher exercise limitation than those with stable weight presenting the same degree of obstruction (24). In addition, the diffusion capacity is, in general, more compromised (21). As the muscle mass and muscle function decrease, the respiratory muscles demands increase to maintain the ventilatory work. As time passes, muscles get less efficient due to fatigue. As the body composition progresses, the respiratory failure becomes, then, common (22).

Another finding of this study was the significant reduction of the COPDG's body bone mass, possibly explained by the physical inactivity (chronic sedentarism) due to dyspnea, which contributes to the skeletal muscle mass reduction (22).

The COPD patients' physical inactivity is a negative influence on the bone mineral density, and may 
reduce its development (22). According to Dalsky. (23), the body weight reduction and bedrest effects on the spine and calcaneus mineral bone content is negative, once they reduce around $1 \%$ per week, contributing to functional capacity decrease.

LeBlanc et al. (24) studies have presented the effect of 17 weeks of bedrest on the skeleton. The loss percentage was different for each part. Calcaneus has lost approximately $10 \%$, femoral trochanter $5 \%$, vertebral spine $4 \%$, femoral neck $4 \%$, tibia $2 \%$ and $1,4 \%$ in a whole body measure.

In conclusion, this study's results show that the body composition is an important prognostic factor for COPD patients. We have also observed the influence of BBM, BBM\%, LM, LM\%, RLL's LM and LLL's LM depletion on the COPDG functional capacity, which reinforces the importance of the body composition assessment by dual-energy x-ray absorptiometry, once it demonstrates satisfactory clinical accuracy. Moreover, it is a useful evaluation and reevaluation parameter in pulmonary rehabilitation programs.

\section{References}

1. Global Initiative for Chronic Obstructive Lung Disease - GOLD. Publications reviewed for global strategy for the diagnosis, management and prevention of COPD. Workshop Report updated 2005. [cited 2012 Jan. 25]. Available at: http://www.goldcopd.org/ Guidelines/guidelines-global-strategy-for-diagnosismanagement-2005-2.html.

2. Dourado VZ, Tanni SE, Vale AS, Faganello MM, Sanchez FF, Godoy I. Manifestações sistêmicas na doença pulmonar obstrutiva crônica. J Bras Pneumol. 2006;32(Suppl.2):161-71. doi:10.1590/S180637132006000200012.

3. Menezes AMB, Jardim JR, Perez-Padilla R, Camelier A, Rosa F, Nascimento O, et al. Prevalence of chronic obstructive pulmonary disease and associated factors: the PLATINO Study in São Paulo, Brazil. Cad Saúde Pública. 2005;21(Suppl.5):1565-73. doi:10.1590/ S0102-311X2005000500030.
4. Takabatake $\mathrm{N}$, Nakamura $\mathrm{H}, \mathrm{Abe} \mathrm{S}$, Inoue $\mathrm{S}$, Hino $\mathrm{T}$, Saito $\mathrm{H}$. The relationship between chronic hypoxemia and activation of the tumor necrosis factor-alpha system in patients with chronic obstructive pulmonary disease. Am J Respir Crit Care Med. 2000;161(Suppl.4):1179-84. PMid:10764309.

5. Ferreira I, Brooks D, Lacasse Y, Goldstein R. Nutrition intervention in COPD: a systematic overview. Chest. 2001;119(Suppl.2):353-63. doi:10.1378/ chest.119.2.353

6. Li YP, Schwartz RJ, Waddell ID, Holloway BR, Reid MB. Skeletal muscle myocytes undergo protein loss and reactive oxygen-mediated NFkappaB activation in response to tumor necrosis factor alpha. FASEB J. 1998;12:871-80. PMid:9657527.

7. Ozalevli S, Ozden A, Itil O, Akkoclu A. Comparison of the set-to-stand test with 6 min walk test in patients with chronic obstructive pulmonary disease. Respir Med. 2007;101:286-93. doi:10.1016/j.rmed.2006.05.007.

8. Lukaski HC. Methods for the assessment of human body composition: traditional and new. Am J Clin Nutr. 1987;46 (Suppl.4):537-56. PMid:3310598.

9. Bolanowski M, Nilsson BE. Assessment of human body composition using dual-energy X-ray absorptiometry and bioelectrical impedance analysis. Med Sci Monit. 2001;7(Suppl.5):1029-33. PMid:11535954.

10. Rabe KF, Hurd S, Anzueto A, Barnes PJ, Buist SA, Calverley P. Global strategy for the diagnosis, management, and prevention of chronic obstructive pulmonary disease: Gold Executive Summary. Am J Respir Crit Care Med. 2007;176(6):532-55. doi:10.1164/ rccm.200703-456SO.

11. Sociedade Brasileira de Pneumologia e Tisiologia. Diretrizes para testes de função pulmonar. J Bras Pneumol. 2002;28(Suppl.3):S1-238.

12. American Thoracic Society. ATS Statement: guidelines for the six-minute walk test. Am J Respir Crite Care Med. 2002;166(1):111-7. PMid:12091180.

13. Dal Corso S, Duarte SR, Neder JA, Malaguti C, Fuccio $\mathrm{MB}$, Castro Pereira CA, et al. A step test to assess exercise-related oxygen desaturation in interstitial lung disease. Eur Respir J. 2007;29(2):330-6. doi:10.1183/09031936.00094006. 
14. Agusti AGN, Sauleda J, Miralles C, Gomez C, Togores B, Sala E, et al. Skeletal muscle apoptosis and weight loss in chronic obstructive pulmonary disease. Am J Respir Crit Care Med. 2002;166(4):485-9. doi:10.1164/ rccm.2108013.

15. Reid MB, Shoji T, Moody MR, Entman ML. Reactive oxygen in skeletal muscle. II. Extracellular release of free radicals. J Appl Physiol. 1992;73(5):1805-9. PMid:1335453.

16. Rennie MJ, Edwards RH, Emery PW, Halliday D, Lundholm K, Millward DJ. Depressed protein synthesis is the dominant characteristic of muscle wasting and cachexia. Clin Physiol. 1983;3(5):387-98. doi:10.1111/ j.1475-097X.1983.tb00847.x.

17. Berry JK, Baum CL. Malnutrition in chronic obstructive pulmonary disease: adding insult to injury. AACN Clin Issues. 2001;12(2):210-9. doi:10.1097/ 00044067-200105000-00005.

18. Casaburi R, Porszasz J, Burns MR, Cariters ER, Chang RS, Cooper CB. Physiologic benefits of exercise trainig in rehabilitation of patients with COPD. Am J Respir Crit Care Med. 1997;155(5):1541-51. PMid:9154855.

19. Killian KJ, Leblanc P, Martin DH, Summers E, Jones NL, Campbell EJM. Exercise capacity and ventilatory, circulatory, and symptom limitation in patients with chronic airflow limitation. Am Rev Respir Dis. 1992;146(4):935-40. PMid:1416421.
20. Santuz P, Baraldi E, Filippone M, Zacchello F. Exercise performance in children with asthma: is it different from that of healthy controls? Eur Respir J. 1997;10(6):1254-60. doi:10.1183/09031936.97.10 061254.

21. Hallstrand TS, Bates PW, Schoene RB. Aerobic conditioning in mild asthma decreases the hyperpnea of exercise and improves exercise and ventilatory capacity. Chest. 2000;118(5):1460-9. doi:10.1378/ chest.118.5.1460.

22. Steinberg FV. El ejercicio en la prevención y tratamiento de la osteoporosis. Madrid: Ediciones CRA; 1989. p. 87-94.

23. Dalsky GP. Exercise: its effect on bone mineral content. Clin Obstet Gynecol. 1987;30(4):820-32. doi:10.1097/00003081-198712000-00006.

24. LeBlanc AD, Driscol TB, Shackelford LC, Evans HJ, Rianon NJ, Smith SM, et al. Alendronate as an effective countermeasure to disuse induced bone loss. J Musculoskelet Neuronal Interact. 2002;2(4):335-43. PMid:15758425.

Received: $12 / 14 / 2011$

Recebido: 14/12/2011

Approved: 07/18/2012

Aprovado: 18/07/2012 